\title{
JUSTIÇA NEGOCIAL E GARANTISMO PENAL: A Fragilização da Epistemologia Garantista a partir da Expansão dos Espaços de Consenso no Processo Penal Brasileiro
}

http://dx.doi.org/10.21527/2176-6622.2021.55.215-229

Recebido em: 22/1/2020

Aceito em: 31/5/2020

Marcelo Herval Macêdo Ribeiro

Autor correspondente. Universidade Federal de Alagoas. Av. Lourival Melo Mota, $\mathrm{s} / \mathrm{n}$ - Tabuleiro do Martins. Maceió/AL, Brasil. CEP 57072-900. http://lattes.cnpq.br/6062945502758177. https://orcid.org/0000-0001-8181-6922. marcelohervalribeiro@hotmail.com

André Rocha Sampaio

Centro Universitário Tiradentes (Unit). Maceió/AL, Brasil.

Marcos Eugênio Vieira Melo

Faculdade da Cidade de Maceió (Fama) e Faculdade Raimundo Marinho (FRM). Maceió/AL, Brasil.

\section{RESUMO}

O presente artigo objetiva avaliar o impacto dos mecanismos de justiça consensual no ordenamento jurídico pátrio, particularmente na sistemática processual penal. Pressupondo que a Constituição da República sufragou uma série de garantias limitadoras do poder punitivo do Estado, pretende-se, aqui, examinar o tensionamento concitado pela emergência dos mecanismos de negociação ante a epistemologia garantista albergada pela Constituição da República Federativa do Brasil (CRFB/88). A partir de uma metodologia predominantemente dialética e fenomenológica e apoiando-se em material bibliográfico já existente, sobretudo de autores e autoras que desenvolvem estudos críticos acerca do direito penal, direito processual penal e criminologia, o trabalho aqui exposto almeja demonstrar que os instrumentos negociais hoje positivados - bem como as atuais propostas de ampliação dos espaços de consenso -, representam potenciais prejuízos à efetiva tutela dos direitos e garantias individuais, haja vista que os referidos institutos materializarão o discurso de que os limites ao poder de punir constituem-se em obstáculos à concretização de uma política criminal eficiente, empreendendo, assim, medidas com vistas à flexibilização dessas garantias.

Palavras-chave: Garantismo. Devido processo legal. Negociação processual penal.

$$
\begin{aligned}
& \text { NEGOTIAL JUSTICE AND CRIMINAL GUARANTEEISM: WEAKENING OF THE DUE PROCESS } \\
& \text { OF LAW ACCORDINGLY THE EXPANSION OF CONSENSUS SPACES IN THE BRAZILIAN CRIMINAL PROCESS }
\end{aligned}
$$

\section{ABSTRACT}

This paper aims to evaluate the impact of consensual justice mechanisms on the national legal system, particularly on the criminal procedural system. Assuming that the Constitution of the Republic has housed a series of limiting guarantees of the punitive power of the State, the intention here is to examine the tension generated from the emergence of negotiation mechanisms in the face of the guarantee epistemology normatized by Constitution of the Federative Republic of Brazil (CFRB/88). The aim is to demonstrate that the current negotiated instruments - as well as the current proposals for expanding consensus spaces - represent potential damages to the effective protection of individual rights and guarantees, given that, based on a utilitarian and efficient logic, these mechanisms will advocate the discourse that limitations on punitive power are obstacles to the realization of an efficient criminal policy, thus undertaking projects aimed at making these guarantees more flexible.

Keywords: Guaranteeism. Due process of law. Criminal procedural negotiation.

\section{SUMÁRIO}

1 Introdução. 2 A epistemologia garantista: o convencionalismo penal e o cognitivismo processual. 3 As garantias constitutivas do devido processo legal e a potencial fragilização da epistemologia garantista em virtude da expansão dos espaços de consenso. $3.1 \mathrm{~A}$ jurisdicionalidade ou a necessidade de submissão à jurisdição. 3.2 A separação entre juiz e acusação, o sistema processual acusatório e a matriz inquisitiva dos institutos negociais. 3.3 A obrigatoriedade da ação penal. 3.4 A presunção de inocência. $3.5 \mathrm{O}$ direito à (ampla) defesa e à garantia do contraditório. 4 Notas conclusivas. 5 Referências. 


\section{INTRODUÇÃO}

A aplicação de uma sanção penal pressupõe, como fundamento ontológico de legitimidade, a necessária existência de uma norma penal prévia - a qual, de um lado, disporá acerca de condutas abstratas violadoras a bens juridicamente relevantes e, de outro, cominará a respectiva sanção àqueles que eventualmente praticarem as preceituadas condutas delituosas. Trata-se, com efeito, de materialização do princípio constitucional da legalidade, expresso pelo brocardo latino "nullum crimen, nulla poena sine lege", segundo o qual "não há crime sem lei anterior que o defina, nem pena sem prévia cominação legal".

O princípio da legalidade - neste caso, nomeadamente o da legalidade penal - constitui uma das mais significativas conquistas civilizatórias modernas. Com o advento do Estado Moderno de Direito, em especial a partir da Revolução Francesa de 1789, passou-se a preconizar que somente a lei positivada seria capaz de conferir legitimidade à atuação estatal. Nesse sentido, a punição a quem rompesse com a ordem social estaria inexoravelmente dependente da existência de uma lei anterior, por meio da qual se estabeleceriam as possíveis consequências a incidir sobre o sujeito que violara o pacto vigente.

Com a instituição desse princípio, o que se almejava, em última análise, era a limitação do poder punitivo do Estado perante as frequentes arbitrariedades praticadas sob a égide do absolutismo. ${ }^{1}$ De fato, na era absolutista o poder estatal legitimava-se a partir da própria soberania exercida pela (e personificada na) figura do monarca, revelando-se despiciendas quaisquer justificativas racionais a limitar o exercício desse poder, na medida em que preponderavam argumentos de natureza fundamentalmente religiosa.

Não obstante, se é lícito afirmar que não há pena sem prévia cominação legal - o que significa que a aplicação da pena impõe a existência de uma lei penal anterior - pode-se igualmente afirmar que não há pena sem a existência de um devido processo legal. Conforme estatui a Constituição Federal em seu artigo 5o, dispositivo que trata dos direitos e garantias individuais, a privação da liberdade ou de bens somente se procede mediante um devido processo legal, em que seja possível assegurar o contraditório e a ampla defesa, "com os meios e recursos a ela inerentes".

Em outras palavras, a aplicação de uma pena exige, como requisito inafastável de legitimidade, a devida observância de um processo legal, no qual se assegure àquele sujeito passível de sofrer as consequências de uma sanção penal uma série de garantias fundamentais, como o contraditório, a ampla defesa, o juiz natural, a imparcialidade, a presunção de inocência, entre outras. Assim, é possível afirmar que pena e processo são dois institutos que caminham umbilicalmente unidos, na medida em que o primeiro somente se legitima a partir da existência (devida) do segundo.

Hodiernamente, no entanto, tem-se presenciado a crescente ascendência de um movimento que, sustentando-se nos ditames de uma racionalidade fundamentalmente eficientista, visa à relativização de certas premissas conformadoras do devido processo a partir da ampliação dos espaços de consenso em matéria criminal. Com efeito, materializando-se desde uma concepção utilitária e instrumentalista (GLOECKNER, 2018), o referido movimento parte da compreensão de que o processo penal deve se apresentar como mecanismo mediante o qual os conflitos sociais sejam resolvidos o mais célere e economicamente possível, ainda que disso resulte um incontornável aviltamento às garantias que limitam a aplicação do poder de punir do Estado.

Diante deste problemático cenário, que faz emergir institutos jurídicos produtos e produtores de um saber-poder autoritário (GLOECKNER, 2018), o presente artigo intenta perscrutar o impacto dos mecanismos de justiça consensual no ordenamento jurídico pátrio, particularmente na sistemática processual penal. 0 objetivo norteador dessa proposta corresponderá ao exame dos tensionamentos concitados pela emergência dos mecanismos de negociação relativamente ao sistema de garantias albergado pela Carta Republicana de 1988, objetivando demonstrar que os instrumentos negociais hoje positivados - bem como as atuais propostas de ampliação dos espaços de consenso - representam potenciais prejuízos à efetiva tutela dos direitos e garantias individuais.

\footnotetext{
Discorrendo acerca dos fundamentos que culminaram com a defesa do primado da legalidade, Pavón afirma que "num primeiro momento [...] se concebeu [a legalidade] como uma garantia de segurança jurídica frente ao poder absoluto do soberano [...] mediante leis certas, o cidadão poderia saber o que estaria proibido ou permitido, adequando sua conduta àquele conhecimento (...) o fundamento do princípio da legalidade consiste na proteção da liberdade individual frente à arbitrariedade; trata-se de instrumentalizar um sistema penal a fim de evitar a arbitrariedade do Estado" (PAVÓN, 2004, tradução nossa).
} 


\section{A EPISTEMOLOGIA GARANTISTA: O CONVENCIONALISMO PENAL E O COGNITIVISMO PROCESSUAL}

Luigi Ferrajoli, distinto jurista italiano, a quem se atribui o mérito por proceder a uma das mais apuradas elaborações teóricas relativamente à ciência do direito - em especial (mas não só) nas disciplinas de direito penal e direito processual penal -, sustenta, em sua obra magna "Direito e Razão" (2002)2 , a existência de uma epistemologia garantista ${ }^{3}$ erigida a partir da coexistência de dois elementos estruturantes: o convencionalismo penal e o cognitivismo processual. Com efeito, é justamente a partir da confluência desses dois elementos (notadamente o segundo) que derivam as garantias constitutivas do devido processo legal.

Pelo convencionalismo penal tem-se que somente o delito formalmente descrito em um tipo legal pode vir a ser penalizado, desde que efetivamente comprovada a prática da conduta delituosa prevista em abstrato. Trata-se de manifestação do princípio da legalidade, "dirigida a excluir, conquanto arbitrárias e discriminatórias, as convenções penais referidas não a fatos, mas diretamente a pessoas e, portanto, com caráter 'constitutivo' e não 'regulamentar' daquilo que é punível" (FERRAJOLI, 2002, p. 31).

Nesse diapasão, afirma Ferrajoli (2002, p. 31, grifos nossos) que

o sentido e o alcance garantista do convencionalismo penal reside precisamente nesta concepção, ao mesmo tempo nominalista e empírica do desvio punível, que remete às únicas ações taxativamente indicadas pela lei, dela excluindo qualquer configuração ontológica ou, em todo caso, extralegal. Auctoritas, non veritas facit legem é a máxima que expressa este fundamento convencionalista do direito penal moderno e por sua vez do princípio constitutivo do positivismo jurídico: o que confere relevância penal a um fenômeno não é a verdade, a justiça, a moral, nem a natureza, mas somente o que, com autoridade, diz a lei.

A partir desse primeiro elemento é possível extrair um conjunto de princípios que consubstanciará o sistema de garantias penais em sentido estrito; princípios representados por questionamentos atinentes a quando e como punir (garantias relativas à pena) e quando e como proibir (garantias relativas ao delito). São eles: 1) princípio da legalidade; 2 ) princípio da retributividade; 3) princípio da necessidade; 4) princípio da lesividade; 5) princípio da materialidade e 6) princípio da culpabilidade.

Por outro lado, o cognitivismo processual ${ }^{4}$ impõe que a pena decorrente da prática de um delito somente se materialize a partir de um raciocínio gnosiológico conduzido no bojo de um processo judicial. Assim, a pena somente poderá ser considerada legítima quando aplicada no curso de um processo penal jurisdicionalizado, em que

a determinação do fato configurado na lei como delito tem o caráter de um procedimento probatório do tipo indutivo, que, tanto quanto possível, exclui as valorações e admite só, ou predominantemente, afirmações ou negações - de fato ou de direito - das quais sejam predicáveis a verdade ou a falsidade processual (FERRAJOLI, 2002, p. 32).

\footnotetext{
É nesta obra que Ferrajoli formulará os princípios que constituem o garantismo penal. Segundo Lívia Almeida Lamas (2010, p. 31), "o modelo penal garantista é uma construção de Luigi Ferrajoli a partir de uma profunda revisão crítica do chamado modelo penal garantista clássico, de matriz ilustrada. Percorrendo não apenas as bases epistemológicas do modelo clássico, mas também seus fundamentos axiológicos externos (critérios de justificação ético-política) e internos (jurídicos), o autor visa alcançar um modelo penal que permita fundamentalmente legitimar ou deslegitimar os sistemas jurídico-penais concretos ou mesmo determinados institutos penais e processuais-penais, de acordo com os parâmetros do Estado Constitucional de Direito".

3 A epistemologia garantista é responsável por estruturar um sistema de garantias penais, que, em sentido lato, corresponde a dez princípios ou axiomas fundamentais. Por questões didáticas, decidiu-se separar os referidos axiomas em dois grupos: um grupo relativo às garantias penais em sentido estrito (que dizem respeito à dogmática penal material), atinentes aos questionamentos sobre "quando e como punir e quando e como proibir", e outro grupo concernente às garantias processuais que mais se aproximam da dogmática penal processual, foco do presente estudo, que se relacionam às questões sobre "quando e como julgar".

4 A partir do cognitivismo processual, é possível depreender quatro outros axiomas, que, somados àqueles extraídos do convencionalismo penal, conformam o modelo epistemológico garantista. São eles: 1) princípio da jurisdicionariedade; 2) princípio acusatório (ou separação entre juiz e acusação); 3) princípio do ônus da prova; 4) princípio do contraditório.
} 
Não obstante, é necessário salientar que, malgrado cada elemento epistemológico mais se aproxime de uma perspectiva dogmática (enquanto o convencionalismo se identifica com a dogmática penal, o cognitivismo mais se aproxima da dogmática processual), o sistema de garantias (em sentido amplo) somente pode ser compreendido a partir de uma análise simultânea e bilateral.

De fato, não haveria que se falar em garantias materiais (como a sujeição à legalidade, por exemplo) se o julgador aplicasse uma pena à míngua da existência de um processo (ou, ainda que existente, fosse este indevido). Da mesma forma, não se poderia imaginar a efetivação de uma certa garantia processual (como a jurisdicionalidade) se o indivíduo fosse julgado por um crime não previsto em lei, ou sancionado a uma pena superior à legalmente autorizada. É precisamente por tal razão que o mestre italiano afirma que

o conjunto das garantias penais seria totalmente insatisfatório se não fosse acompanhado do conjunto correlato e, por assim dizer, subsidiário das garantias processuais [...] As garantias penais, ao subordinar a pena aos pressupostos substanciais dos crimes - a lesão, a conduta e a culpabilidade -, são tanto efetivas quanto mais estes forem objeto de um juízo, em que sejam assegurados ao máximo a imparcialidade, a verdade e o controle. É por isso que as garantias processuais, e em geral as normas que disciplinam a jurisdição, são ditas também "instrumentais" no que tange garantias e às normas penais, estas chamadas, por sua vez, "substanciais" (FERRAJOLI, 2002, p. 431-432).

O que se observa, com efeito, é um "nexo estrutural e funcional" entre os diferentes elementos da epistemologia garantista, porquanto somente se pode admitir a estrutura de um processo penal se este existir para julgar crimes previstos em lei, da mesma forma que apenas é possível aplicar uma sanção penal mediante o (devido) funcionamento de um processo.

Feitas as considerações supra, convém, agora, analisar o complexo de garantias que constitui parâmetros limitadores (e, por tal razão, legitimadores) da aplicação do poder de punir do Estado, as quais se consubstanciam na cláusula constitucional do due process of law ou devido processo legal. Paralelamente à exposição dos axiomas que conformam o sistema garantista, proceder-se-á a uma análise crítica quanto ao fenômeno de expansão dos mecanismos de justiça consensual, objetivando demonstrar de que maneira estes institutos potencialmente se apresentam como elementos incompatíveis a uma estrutura epistemológica destinada à contenção do arbítrio estatal.

\section{AS GARANTIAS CONSTITUTIVAS DO DEVIDO PROCESSO LEGAL E A POTENCIAL FRAGILIZAÇÃO DA EPISTEMOLOGIA GARANTISTA EM VIRTUDE DA EXPANSÃO DOS ESPAÇOS DE CONSENSO}

\subsection{A jurisdicionalidade ou a necessidade de submissão à jurisdição}

A primeira (e quiçá mais importante) garantia constitutiva de um legítimo processo penal, da qual derivam todas as demais, é a jurisdicionalidade (jurisdicionariedade ou princípio da submissão à jurisdição), representada pelo axioma nulla poena, nulla culpa sine iudicio.

Conforme preleciona Ferrajoli, é possível compreender esta garantia a partir de duas perspectivas que, embora distintas, revelam-se inextricavelmente complementares: a primeira diz respeito à jurisdicionariedade em sentido lato, segundo a qual os pressupostos do delito - tipicidade, antijuridicidade e culpabilidade - devem ser evidenciados por meio de um expediente jurisdicionalizado, vale dizer, a partir de um processo penal; a segunda, relativa à jurisdicionariedade em sentido estrito, preconiza que a cognição judicial deve se encontrar amparada em premissas limitadoras, "submetendo as hipóteses acusatórias à prova e refutação" (FERRAJOLI, 2002, p. 441).

Para que esta garantia se efetive, é importante salientar que exige o postulado não apenas a figura de um juiz, mero condutor de um processo; é preciso, com efeito, que esse juiz seja "imparcial, natural e comprometido com a máxima eficácia da própria Constituição" (LOPES JR., 2017, p. 58). Por tal razão, afirma 
Ferrajoli (2002, p. 431) que a materialização do princípio da jurisdicionalidade (notadamente em seu viés estrito) depende da observância de outras garantias dele derivadas, ${ }^{5}$ que serão mais detidamente analisadas nos tópicos seguintes.

Neste momento, contudo, calha asseverar que o crescente movimento observado no campo de saber jurídico, correspondente à incorporação de mecanismos de negociação em matéria criminal, afigura-se potencialmente problemático, na medida em que um dos objetivos aspirado por esse movimento diz respeito à simplificação (e, em determinados casos, ao completo afastamento) de determinadas regras que constituem a matriz ontológica do processo.

Nos Estados Unidos, por exemplo, o plea bargaining ${ }^{6}$ pode ser considerado regra (pesquisas mostram que mais de $90 \%$ dos casos são resolvidos por esse instituto ${ }^{7}$ ), posto que os julgamentos perante o Tribunal do Júri (Trial by Juri) estão sendo cada vez menos utilizados em razão de pretensos custos, complexidades e riscos que deles decorrem. Dessa forma, apesar de, neste país, o acusado possuir direito a ser julgado por um júri imparcial ${ }^{8}$, ele pode, em virtude da realização de um acordo com o Ministério Público, renunciar a esse direito e admitir a prática criminosa diante da concessão de vantagens, sobrevindo, por conseguinte, a imposição de uma pena sem o devido (e constitucionalmente previsto) julgamento pelo júri. ${ }^{9}$

Nessa toada, calha assentar expansão das justiças negociais, que traz como pano de fundo a "eficiência" do processo penal. Baseando-se na ideologia político-criminal de que é possível perseguir todos os fatos criminalizados, bem como no funcionamento do sistema penal na resolução desses crimes, entende-se essas negociações como uma forma de aliviar a demanda judicial e, ao mesmo tempo, "resolver" o caso penal. A ideia de eficiência fundamenta-se, contudo, na errônea percepção de que o processo deverá ser simples e rápido. Conforme ensina Anitua: "quem sai mais beneficiada com este sistema é a pretensão punitiva do Estado, que assim alcança seu objetivo em maior número, a menor custo, mais rapidamente e sem ter que debater, nem internamente e nem público, sobre a finalidade última da tarefa que realiza" (ANITUA, 2017, p. 374).

\subsection{A separação entre juiz e acusação, o sistema processual acusatório e a matriz inquisitiva dos institutos negociais}

A segunda garantia que consubstancia o devido processo legal (e que deriva fundamentalmente do princípio da jurisdicionalidade) é a separação entre juiz e acusação. Característica primordial de um processo penal democrático, trata-se de elemento sine qua non - embora não exclusivamente ${ }^{10}$ - a uma estrutura epis-

\footnotetext{
5 Em relação às garantias derivadas do princípio da jurisdicionariedade, Ferrajoli subdivide-as em dois conjuntos. O primeiro conjunto diz respeito às garantias orgânicas, relativas à formação do juiz, no qual estão inseridas "a independência, a imparcialidade, a responsabilidade, a separação entre juiz e acusação, o juiz natural, a obrigatoriedade da ação penal e outras"; o segundo conjunto refere-se às garantias procedimentais, relativas à formação do juízo (ou cognição), em que se incluem "a contestação de uma acusação exatamente determinada, o ônus da prova, o contraditório, a modalidade dos interrogatórios e dos outros atos instrutórios, a publicidade, a oralidade, os direitos da defesa, a motivação dos atos judiciários e outros". Calha salientar, todavia, que os dois aludidos conjuntos guardam consigo "conexões lógicas e funcionais", que serão responsáveis por ora conformar uma episteme acusatória ora estruturar um modelo inquisitório.

6 Plea bargaining consiste em um procedimento negocial realizado tipicamente nos ordenamentos jurídicos anglo-saxônicos, no qual o réu, em um caso criminal, abre mão do seu direito a julgamento em troca de uma redução na acusação e/ou na sentença (HEUMANN, 1981, p. 1). Cf. ALSCHULER, 1979, p. 1.

8 Nos Estados Unidos, essa garantia constitucional encontra-se positivada na Sexta Emenda à Constituição Americana, cujo artigo assim dispõe: "Artigo 6 - Em todos os processos criminais o acusado terá direito a julgamento rápido e público, por júri imparcial no Estado e distrito onde o crime houver sido cometido, distrito esse que será previamente delimitado por lei [...]" (ESTADOS UNIDOS. U.S. Constitutional Amendments Disponível em: https://constitution.findlaw.com/amendments.html. Acesso em: 20 abr. 2019. Tradução nossa. Grifos nossos).

9 Cf. VASCONCELLOS, 2015.

${ }^{10}$ LOPES JR. (2017, p. 64) adverte, com elogiável lucidez, que "é insuficiente pensar que o sistema acusatório se funda a partir da separação inicial das atividades de acusar e julgar. Isso é um reducionismo que desconsidera a complexa fenomenologia do processo penal. De nada basta uma separação inicial, com Ministério Público formulando a acusação, se depois, ao longo do procedimento, permitirmos que o juiz assuma um papel ativo na busca da prova ou mesmo na prática de atos tipicamente da parte acusadora".

Por tal motivo, sustenta-se que, além de uma simples cisão entre as atividades de acusar e julgar, a sistemática acusatória reclama o necessário monopólio da gestão probatória a cargo do órgão acusador, como mecanismo essencial apto a evitar os equívocos cognitivos próprios de um sistema inquisitório, como se verá mais adiante.
} 
têmica acusatória, responsável por assegurar o legítimo desenvolvimento do raciocínio judicial, porquanto abalizador das condições necessárias à materialização das garantias fundamentais do contraditório, imparcialidade e ampla defesa.

Verdadeiramente, observa-se que é apenas na sistemática processual acusatória, em que se promove uma cristalina separação entre as distintas atividades dos atores processuais, e, mais do que isso, na qual a carga probatória recai exclusivamente sobre a acusação (e não resta avocada pelo juiz), que se afigura possível efetivar a imparcialidade. Por reclamar do julgador uma postura passiva, alheia e desinteressada, esse sistema permite o afastamento ante as contaminações cognitivas típicas de um sistema inquisitivo, como o surgimento de quadro mentais paranoicos e a prevalência das hipóteses sobre os fatos (CORDERO, 1986, p. 51-52).

Nessa esteira, discorre Ferrajoli (2002) que

[...] pode-se chamar acusatório todo sistema processual que tem o juiz como um sujeito passivo rigidamente separado das partes e o julgamento como um debate paritário, iniciado pela acusação, à qual compete o ônus da prova, desenvolvida com a defesa mediante um contraditório público e oral e solucionado pelo juiz, com base em sua livre convicção. Inversamente, chamarei inquisitório todo sistema processual em que o juiz procede de ofício à procura, à colheita e à avaliação das provas, produzindo um julgamento após uma instrução escrita e secreta, na qual são excluídos ou limitados o contraditório e os direitos da defesa (p. 452).

De fato, no modelo inquisitivo, antipodal à sistemática acusatória, é possível verificar uma "aglutinação de funções na mão do juiz e atribuição de poderes instrutórios ao julgador, senhor soberano do processo", não havendo "estrutura dialética e tampouco contraditória", assim como inexiste a "imparcialidade, pois uma mesma pessoa (juiz-ator) busca a prova (iniciativa de gestão) e decide a partir da prova que ela mesma produziu" (LOPES JR., 2017, p. 42).

Nesse sentido, Salo de Carvalho aduz que a máquina inquisitiva se caracteriza ontologicamente "pela exclusão do contraditório, pela ausência de ampla defesa e pela inversão da presunção de inocência" (CARVALHO, 2015, p. 141). Ademais, com supedâneo no magistério de Franco Cordero, assevera ainda que "pode-se identificar o estilo inquisitorial a partir de duas constatações: a) sobrevalorização da imputação em relação à prova, configurando o primado das hipóteses sobre os fatos; e b) a conversão do processo em psicoscopia, ao estabelecer rito fatigante e isento de forma" (CARVALHO, 2015, p. 141).

É imperioso salientar que a tendência contemporânea de expansão dos espaços de consenso no processo penal, objeto do presente trabalho, revela-se essencialmente deletéria na medida em que possibilita flexibilizações a garantias fundamentais (e, por tal razão, não sujeitas à relativização), constitutivas de um sistema processual acusatório. O que se verifica, nesse sentido, é que institutos negociais - como a barganha penal - enfraquecem a posição do acusado como sujeito de direitos, deslocando-o à mera posição de objeto de intervenção, de tal maneira se aproximando, por conseguinte, do modelo autoritário inquisitorial.

Como afirma SCHÜNEMANN (2017, p. 192),

com o plea bargaining vem a ser aniquilada uma das maiores conquistas evolutivas do processo penal reformado na Europa: a posição de sujeito de direito do acusado. Afinal, o plea bargaining ocorre de um modo geral sem a presença do próprio acusado, que nesse sentido acaba sendo completamente mediatizado por seu advogado.

No mesmo sentido, observa Ignacio Anitua que os mecanismos de justiça consensual materializam os dois principais elementos do modelo inquisitivo - a saber, o segredo e a confissão -, de sorte que "apesar de ser realmente uma 'importação' de um sistema com tradição histórica voltada ao modelo processual acusatório, não é em vão a comparação realizada por muitos autores deste mecanismo com as técnicas mais tradicionais do sistema inquisitivo" (ANITUA, 2017, p. 367).

Isso ocorre, segundo o autor, porquanto

ao se buscar a confissão, se valida esta como probatio probatissima, substituindo a atividade probatória. Isto é a base do sistema inquisitivo. Significa um retorno ao sistema inquisitivo se quem pactua é o Estado, que coage o imputado com uma ameaça penal maior para que este colabore evitando o julgamento em contraditório (...) O caráter inquisito do juízo abreviado verifica a intenção de condenar sobre a base da confissão obtida coativamente (ANITUA, 2017, p. 369). 
Com efeito, as propostas de expansão dos espaços de consenso previstas no Projeto de Reforma do Código de Processo Penal (PL 8.045/2010), ${ }^{11}$ nomeadamente aquelas normatizadas no Capítulo III (artigos 308 et seq.), preceituam que a formalização do acordo penal condicionar-se-á à "confissão em relação aos fatos imputados na peça acusatória", exigindo ainda o dispositivo que o acusado expressamente manifeste desejo de dispensa da produção probatória, com vistas a suprimir, por conseguinte, a fase instrutória, tornando mais célere a resolução do caso submetido à apreciação jurisdicional.

Não obstante, um dos mais problemáticos efeitos concitados em razão do supracitado comando normativo diz respeito ao fato de que, por supor o término sumário do julgamento mediante a supressão da audiência de instrução, esse mecanismo impossibilita o escorreito desenvolvimento da dialética processual e, por conseguinte, viola o imperativo de que o pronunciamento judicial seja perfilhado por elementos probatórios confiáveis. O que ocorre, nesse sentido, é a primazia dos elementos de informação coligidos na investigação preliminar (unilateral, discricionária e, geralmente, sigilosa), resultando, assim, num processo fundamentalmente inquisitório.

É por este motivo que Schüneman (2017, p. 242), debruçando-se sobre o aparente paradoxo existente entre o modelo processual penal historicamente adversarial - como aquele tradicionalmente atribuído aos países anglo-saxônicos -, por um lado, e a ressignificação inquisitiva verificada na aplicação prática dos mecanismos de consenso, por outro, assevera que "neste sistema, por trás do disfarce do procedimento do tribunal do júri, deságua na prática em nada mais, nada menos, do que no velho modelo do processo inquisitorial". Isso acontece, explica o autor, haja vista que os dispositivos negociais - notadamente o plea bargaining - resultaram

em uma radical revolução no processo penal: a audiência de instrução e julgamento fora amplamente abolida e substituída por um guilty plea do acusado, que dele é praticamente comprado através de uma suposta diminuição da pena [...] Neste ponto faz-se notória uma outra debilidade do tribunal do júri. Este, por conta de seus inconvenientes e suas complicações, exigiu do ponto de vista da práxis uma correção. $O$ fato de que esta correção conduziria de um modo geral a uma vasta abolição da audiência de instrução e julgamento resultou no seguinte paradoxo: o modelo processual adversarial [...] não mais conseguia responder às exigências da práxis [...] originando-se um resultado absolutamente oposto ao almejado, qual seja, a ampla extinção da audiência de instrução e julgamento através da aceitação do resultado da investigação preliminar por meio de um mero plea bargaining (SCHÜNEMAN, 2017, p. 254, grifos nossos).

Saliente-se, por oportuno, que os efeitos deletérios concitados em virtude da primazia conferida às declarações autoincriminatórias, em especial a coercibilidade ínsita aos expedientes negociais, bem como a problemática concernente aos prejuízos decorrentes da supressão da fase processual instrutória, serão mais detidamente analisadas no tópico relativo à garantia da presunção de inocência.

\subsection{A obrigatoriedade da ação penal}

O princípio da obrigatoriedade consiste em premissa lógica da ação penal pública e importa na condição de que, uma vez satisfeitos os requisitos autorizadores da instauração do processo (fumus commissi delicti, punibilidade concreta, legitimidade de parte e justa causa), deve o órgão ministerial, sem espaço de discricionariedade, oferecer a ação penal visando à apuração do pretenso fato delituoso. Trata-se de princípio que deriva da própria natureza pública do processo, e que, assim como a garantia anteriormente analisada, tem sua origem na cláusula de reserva à jurisdição. ${ }^{12}$

O fundamento teleológico que subjaz a existência deste imperativo corresponde à necessidade de materializar os fins abstratos que justificam a aplicação da sanção penal, transmitindo à sociedade a mensagem de que condutas desviantes serão efetivamente passíveis de responsabilização. Nessa toada, costuma a dou-

\footnotetext{
11 Igual preceito extrai-se da Lei no 13.964/2019, supramencionada, haja vista que o instituto negocial ali encampado exige, para fins de proposição do acordo, a confissão formal e circunstanciada da prática delituosa pelo suposto autor do fato criminoso.

12 “A obrigatoriedade da ação penal é só um aspecto ou, se quisermos, um corolário de outras essenciais características estruturais do sistema garantista (...) Com a afirmação do caráter público do direito penal (...) também a acusação perdeu progressivamente sua natureza privada originária e assumiu natureza e modalidade inteiramente públicas (...) com a instituição, ao lado dos órgãos judicantes, de um acusador ou Ministério Público" (FERRAJOLI, 2002, p. 455 et seq.).
} 
trina afirmar que o princípio da obrigatoriedade coincide com a legalidade, ${ }^{13}$ uma vez que impõe ao órgão acusador o ônus inalienável de buscar efetivar - quando preenchidos os requisitos supramencionados - as prescrições legalmente previstas.

Decorre desta garantia outro princípio de igual relevo, qual seja, a indisponibilidade (ou irrevogabilidade), uma vez que "não apenas está o Ministério Público obrigado a denunciar (ou pedir o arquivamento), senão que, uma vez iniciado o processo, não pode ele desistir, dispor da ação penal" (LOPES JR., 2017, p. 201). De fato, nenhum sentido faria se o órgão ministerial estivesse vinculado à propositura da ação penal e, no curso do processo, manifestasse vontade em dela desistir.

Em contraposição à obrigatoriedade, tem-se o princípio da oportunidade, norteador das ações penais de natureza privada, cuja principal característica diz respeito à faculdade que se apresenta à vítima em oferecer (ou não) a ação penal, pois o que se observa aqui, antes de uma obrigação, é um direito do ofendido em analisar "a conveniência de submeter seu caso penal ao processo, ponderando as vantagens e desvantagens" (LOPES JR., 2017, p. 201).

Não obstante se tratar de princípio típico das ações penais de natureza privada, o que se tem constatado em tempos hodiernos é uma vertiginosa ampliação dos espaços de discricionariedade (oportunidade) também às ações penais de natureza pública. A Lei no 9.099/95 (Lei dos Juizados Especiais), por exemplo, expandiu as referidas hipóteses aos delitos de menor potencial ofensivo: estando preenchidos os requisitos legais, poderá ${ }^{14}$ o Ministério Público apresentar proposta de transação penal, deixando, por conseguinte, caso aceito o acordo, de oferecer denúncia em desfavor do indiciado, mesmo tratando-se de suposto delito cuja natureza da ação seja pública.

Nesse mesmo sentido, o instituto da colaboração premiada, recepcionado no ordenamento pátrio por meio da Lei no 12.850/2013, estabelece um espaço relativamente amplo de discricionariedade, na qual se confere à parte acusadora a possibilidade de oferecer uma série de benefícios penais e/ou processuais ao acusado que tenha contribuído eficazmente com a persecução penal. Esses benefícios podem consistir em perdão judicial, redução da pena em até dois terços, substituição da pena privativa de liberdade por restritiva de direitos, redução da pena até metade ou progressão de regime (nestes dois últimos casos, quando a colaboração houver ocorrido em sede de execução penal), assim como o não oferecimento da denúncia.

Aplicado em casos paradigmáticos (notadamente no âmbito da Operação Lava-Jato), o instituto em comento não se afigurou indene de críticas. Com efeito, o respeitável setor doutrinário tem sustentado as aporias concernentes ao emprego desse mecanismo no ordenamento jurídico brasileiro. Entre outras razões, tem-se ventilado as numerosas lacunas observadas no diploma legal, o que termina por atribuir indevidamente ao Poder Judiciário a competência de suprir as deficiências legislativas; a ausência de regular controle judicial, ensejando acordos que exorbitam os limites da lei ${ }^{15}$; a excessiva concessão de poder ao órgão acusador,

\footnotetext{
13 "Conforme posição majoritária, o princípio da legalidade no processo penal corresponde à obrigatoriedade da persecução punitiva, ou, nas palavras de Jacinto Coutinho, "é praxe ser tratado (o princípio da obrigatoriedade) por princípio da legalidade, em face de fundar um dever do órgão oficial de acusação' [...] Há um dever de acusação decorrente da lei que se impõe quando houver indícios de materialidade e autoria suficientes da ocorrência de uma infração penal, o que não pode ser influenciado ou renunciado por razões discricionárias ou por motivos alheios à simples averiguação da existência ou não do crime a partir das provas obtidas." (VASCONCELLOS, 2015, p. 181).

${ }^{14} \mathrm{Em}$ que pese o artigo 76 da Lei dos Juizados Especiais estatuir que o Ministério Público "poderá propor" transação penal - o que, à primeira vista, conduziria ao raciocínio de que se trata de mera faculdade/liberalidade do órgão acusador -, preconiza respeitável doutrina que a transação penal consiste, na verdade, em direito público subjetivo do suposto autor do fato. Nesse sentido, tem sido comum a afirmação de que a discricionariedade percebida nesse instituto seria "regrada" - isto é, delimitada pela lei -, uma vez que, estando satisfeitos os requisitos legais, não poderia o Parquet furtar-se do dever de apresentar a proposta. Cumpre mencionar, todavia, que a jurisprudência pátria ainda não pacificou entendimento a respeito da matéria, não sendo escassas as decisões, inclusive de Tribunais Superiores, que reconhecem ser faculdade do órgão acusador oferecer ou não o benefício.

${ }^{15}$ Alexandre Morais da Rosa e Aury Lopes Jr. (2018, p. 27) aludem a uma sentença penal condenatória prolatada no âmbito da operação Lava Jato, em que o sujeito fora condenado a 15 anos e 10 meses de prisão a ser cumprida em "regime de reclusão doméstica", ao que, passado algum tempo, progrediria ao regime "semiaberto diferenciado" e, finalmente, depois de dois anos, a regime aberto. Evidentemente, esse sistema atípico de cumprimento de pena não encontra amparo no diploma que recepcionou o instituto da colaboração, representando, portanto, indevida "execução penal à la carte".
} 
desequilibrando o jogo processual (paridade de armas) e fragilizando o Estado Democrático de Direito ${ }^{16}$; e os acordos prevendo aplicações de penas (inclusive privativas de liberdade) a despeito da inexistência de processo e, portanto, à míngua da observância das garantias constitutivas do devido processo legal.

De fato, tanto a transação penal, prevista na Lei de Juizados Especiais, quanto a colaboração premiada, evidenciam a tendência hodierna de expansão do princípio da oportunidade aos delitos de ação penal pública. Conforme aponta Vasconcellos, "os mecanismos consensuais se instrumentalizam na seara processual a partir de critérios de oportunidade, ou seja, para que se efetive a decisão tomada impõe-se que o órgão acusador deixe de sustentar a persecução penal até seu desfecho habitual" (VASCONCELLOS, 2015, p. 53). Nesse mesmo sentido, Diego Díez (1999, p. 191) afirma que "naturalmente, existe uma íntima relação entre oportunidade e consenso, visto que a forma de se efetivar as soluções consentidas com relação ao tratamento penal do réu não é outra que o uso da oportunidade".

É imperioso destacar, contudo, que a referida tendência consiste em fenômeno sobremaneira problemático, na medida em que favorece relativizações a garantias fundamentais constitutivas de um sistema epistemológico garantista. É conveniente registrar, nesse sentido, o escólio de Ferrajoli (2002, p. 456), segundo o qual

entende-se que essa discricionariedade e disponibilidade [...] representam uma fonte inesgotável de arbítrios: arbítrios por omissão, não sendo possível qualquer controle eficaz sobre os favoritismos que podem sugerir a inércia ou a incompletude da acusação; arbítrios por comissão, sendo inevitável, como a experiência ensina, que o plea bargaining se torne a regra e o juízo uma exceção, preferindo muitos imputados inocentes declararem-se culpados em vez de se submeterem aos custos e aos riscos do juízo. $O$ sistema [...] apresenta indubitavelmente a vantagem da máxima eficiência [...] mas essa vantagem é alcançada ao preço de uma pesada conotação burocrática e policialesca da maior parte da justiça penal e de uma vistosa discriminação contra tantos que, pelas condições econômicas, são forçados a abdicar, como se fosse um luxo inacessível, não só, como entre nós, de uma defesa adequada, mas até mesmo de um julgamento justo.

Com efeito, embora assente na ideia de que ao acusado seria conferida a oportunidade de obter uma vantagem caso admitida a propositura do acordo, fato é que muitos indivíduos, em razão das inúmeras circunstâncias coercitivas que subjazem o procedimento negocial, acabam cedendo à proposta de acordo, mesmo não sendo eles, efetivamente, os autores das imputadas condutas delituosas. Tal contexto, registre-se, resta largamente acentuado em razão do incontestável cenário de desigualdade social existente no país, que acaba se reproduzindo também no sistema de justiça criminal, não apenas pela seletividade dos indivíduos que são mais comumente incriminados, mas, também, pela frequentemente limitada assistência jurídica à disposição dessas pessoas. ${ }^{17}$

\subsection{A presunção de inocência}

O processo penal reflete majoritariamente o que o Estado se propõe a ser. Em outras palavras, trata-se do que Cunha Martins (2013, p. 3) afirma: o processo é microcosmo do Estado de Direito. Em termos, contudo, de "circularidade sistêmica, estando o sistema processual inserido no sistema judiciário e este no sistema constitucional, o primeiro expressa, desejavelmente, os princípios adotados nesse último" (CUNHA MARTINS, 2013, p. 3). Isto é, em um sistema em que a Constituição está abrangendo os demais subsistemas, estes deve(ria)m basear-se em seus princípios fundadores.

\footnotetext{
${ }^{16}$ Como aponta Rosmar Alencar (2018, p. 431 et seq.), "a acusação de setor doutrinário prestigiado é a de que os órgãos envolvidos na persecução penal têm incidido em exercício de poder que não lhes foi sufragado pela ordem jurídica brasileira vigente. Como consequência, o Estado Democrático de Direito estaria fragilizado. O assunto tomou maior repercussão em razão do uso reiterado do instituto 'delação premiada' e da sua divulgação instantânea pelos meios de comunicação (grande imprensa - trial by media - e redes sociais), tendo, como temática, o discurso de combate à corrupção.

17 Não obstante a Defensoria Pública exerça papel fundamental na luta contra a desigualdade processual, ao oportunizar acesso à justiça a uma quantidade significativa de indivíduos, cumpre observar que ainda existe, no país, considerável déficit relativamente à extensão territorial dos atendimentos realizados. Segundo estudo realizado pelo Ipea, há uma quantidade considerável de cargos não providos (cerca de 40\%), o que acaba se refletindo também na quantidade de comarcas que dispõem de atendimento (a Defensoria está presente em apenas $28 \%$ das comarcas). Nesse sentido, conferir: Instituto de Pesquisa Econômica Aplicada - Ipea. Mapa da Defensoria Pública no Brasil. Disponível em: http://www.ipea.gov.br/sites/mapadefensoria/defensoresnosestados. Acesso em: 22 jan. 2020.
} 
Nesse contexto, toda a evolução e afirmação dos direitos e garantias fundamentais ao longo da história vão se consolidar, ao menos de forma positivada, nas constituições contemporâneas, de modo a limitar o poder e a proibir seu excesso: trata-se do Estado Democrático de Direito, que visa à limitação dos poderes estatais na esfera dos indivíduos e a consolidação dos direitos e garantias fundamentais. A noção de um modelo processual que se funda nessas premissas é imprescindível para que haja o mínimo de democracia processual. Para tanto, deverá haver uma base principiológica uníssona fundada no microssistema do processo penal, que abarque garantias essenciais as quais possuam uma codependência, ou seja, que ao se desrespeitar uma garantia afeta-se, de forma reflexa, as outras garantias fundantes (BARROS, 2009, p. 15-17).

No processo penal, as garantias constitucionais mais relevantes são referentes "às liberdades públicas afetadas pela persecução penal" (PRADO, 2014, p. 16). A garantia da presunção de inocência é, então, consagrada no Estado Democrático de Direito e entendida no processo penal moderno como limite ao poder punitivo estatal (MUÑOZ CONDE, 2008, p. 73). Seu papel consiste em tratar o imputado como inocente até o trânsito em julgado de eventual decisão condenatória, promovendo um estado de incerteza durante a persecução penal, de tal sorte que a punição apenas se legitime quando superado esse estado em uma estrutura que permita às partes colaborarem dialeticamente na formação da convicção do julgador (PRADO, 2014, p. 17-19).

Assim, levando ao plano da evidência antes posto, a presunção de inocência deverá funcionar como estabilizadora de expectativas em uma lógica acusatória, de forma a significar, por meio do mecanismo da confiança por ela desencadeada, a realização de um desejo de preenchimento de um sistema acusatório. Em outros termos, a evidência deverá atuar como coadjuvante do dispositivo processo penal, constrangendo-a com a prova em contraditório e com o assentimento da presunção de inocência, exatamente para comungar esforços na contensão das pulsões inquisitoriais, vedando, assim, o juiz de produzir qualquer diligência probatória em caso de dúvida (AMARAL, 2013, p. 109-112).

Incluída no rol de garantias responsáveis por estruturar um sistema processual legítimo, a presunção de inocência caracteriza-se indiscutivelmente como uma das mais importantes ferramentas dispostas ao indivíduo perante as consequências decorrentes de eventual sujeição ao poder estatal. Tamanha é sua relevância, que Amilton Bueno de Carvalho (2001) alude ao fato de que "o princípio da presunção de inocência não precisa estar positivado em lugar nenhum: é pressuposto, neste momento histórico, da condição humana” (p. 51).

Malgrado isso, a Carta Cidadã Brasileira, erigida no bojo do movimento neoconstitucionalista, reconheceu a importância de que o princípio em comento se reveste, preconizando, em seu artigo 50, inciso LVII, que "ninguém será considerado culpado até o trânsito em julgado da sentença penal condenatória". Nesse mesmo sentido, a Convenção Americana de Direitos Humanos (CADH ou "Pacto San José da Costa Rica"), recepcionada no ordenamento pátrio com status de norma supralegal, dispôs, em seu artigo $8^{\circ}$, alusivo às garantias judiciais, que "toda pessoa acusada de delito tem direito a que se presuma sua inocência enquanto não se comprove legalmente sua culpa".

Trata-se, com efeito, de princípio reitor do processo democrático, a partir do qual é possível extrair três significados distintos, não obstante sejam eles entre si complementares, quais sejam: presunção como norma de tratamento, norma probatória e norma de juízo (MORAES, 2010, p. 424-476).

O primeiro desses sentidos diz respeito a uma norma (ou dever) de tratamento, que incide tanto na dimensão interna quanto externa ao processo. Nesse viés, a garantia de inocência impõe, de um lado, que o réu seja tratado, no curso do processo, como inocente, de tal sorte que a determinação de medidas constritivas (como as prisões cautelares) sobrevenha apenas em casos excepcionalíssimos, quando presentes motivos aptos a justificar o édito acautelatório. ${ }^{18}$ Por outro lado, impõe-se também que o réu seja protegido ante a indevida publicização precoce do processo penal, evitando-se a "abusiva exploração midiática em torno do fato criminoso" (LOPES JR., 2017, p. 97) e o "bizarro espetáculo montado pelo julgamento midiático" (LOPES JR., 2017, p. 97).

\footnotetext{
${ }^{18}$ A constrição cautelar da liberdade individual exige, necessariamente, a presença de dois requisitos essenciais, sem os quais não há de se cogitar em cerceamento provisório. São eles: o fumus comissi delicti (que se traduz em prova da materialidade do crime e indícios suficientes de autoria) e o periculum libertatis (representado pelo provável prejuízo que o estado de liberdade pode ensejar em relação à ordem pública, à ordem econômica, à instrução criminal ou à aplicação da lei penal).
} 
Além disso, infere-se da presunção de inocência uma norma probatória, apresentando-se como exigência de que os instrumentos de prova trazidos à baila sejam efetivamente lícitos, vale dizer, produzidos em conformidade com os ditames constitucionais e legais. Nesse sentido, se alguma das partes, por ventura, trouxer ao processo informação obtida a partir de recursos espúrios - como a tortura, por exemplo - imperioso será concluir pela inadmissibilidade da eventual informação obtida como argumento idôneo a fundamentar uma hipotética decisão condenatória.

Por essa razão, afirmam Lopes Jr. e Gloeckner que "a prova a ser produzida pela acusação não pode ser qualquer prova, mas deve ser licitamente obtida [...] na dúvida sobre a licitude da produção probatória, deve a prova ser excluída" (LOPES JR.; GLOECKNER, 2014, p. 78). Da mesma forma, não se revela suficiente que o "Ministério Público tenha a carga processual de provar as imputações alegadas contra o réu e que tenha procedido de forma lícita. É necessário que tal prova seja incriminadora, isto é, forte o bastante para se determinar, com precisão, materialidade e autoria do crime" (LOPES JR.; GLOECKNER, 2014, p. 78).

Finalmente, é possível extrair da presunção de inocência uma norma de juízo (ou regra de julgamento). Nessa acepção, preconiza-se que o raciocínio judicial, levado a cabo pelo julgador, deve perfilhar uma pré-ocupação (CUNHA MARTINS, 2011, p. 11) ou predisposição cognitiva diante da inocência do acusado. Enquanto o Ministério Público não houver logrado demonstrar cabalmente a existência do crime e a correspondente autoria delitiva - pois, repise-se, a carga da prova na sistemática acusatória é atribuição exclusiva do acusador - deve o magistrado considerar que aquele submetido ao processo penal é inocente, decidindo, caso findada a instrução, pela absolvição do réu.

Uma questão que se faz mister pontuar diz respeito à sistemática subversão ao postulado da presunção de inocência levado a cabo pelos mecanismos de justiça negocial. Com efeito, ao atribuírem sobrelevada relevância às declarações autoincriminatórias externalizadas pelo imputado, os institutos negociais promovem um inquestionável retorno ao ultrapassado sistema tarifado de provas, no qual a confissão se afigurava como regina probatium, isto é, rainha das provas. Como observa Vasconcellos (2015, p. 176-177), "ao se legitimar um mecanismo de barganha, acaba-se por afastar toda a construção das regras processuais como limitadoras da formação da culpa na justiça criminal".

Nesse diapasão, tem-se que a presunção de inocência - notadamente em sua perspectiva probatória - resta largamente fragilizada, porquanto, ao se promover o afastamento da fase instrutória processual, mediante a simples homologação de uma declaração autoincriminatória, não se queda possível confrontar a conformidade dos elementos informativos preliminarmente coligidos (num procedimento fundamentalmente inquisitório, consoante já se observou) em relação às normas processuais que efetivamente condicionam o desenvolvimento do raciocínio jurisdicional. O efeito disso nada mais é do que um "evidente retorno ao passado, que desautoriza a democrática imposição de necessidade de provas sólidas e lícitas para a fragilização da presunção de inocência".

Ademais, calha asseverar que, ao se proceder às negociações, costuma-se oferecer ao acusado duas alternativas: ou ele aceita a proposta de acordo, declarando-se culpado e renunciando ao direito de ter um devido processo legal, tudo em troca de uma sanção mais leniente, ou ele recusa o acordo e se sujeita ao risco de ter de cumprir, caso condenado, uma pena muito mais gravosa do que aquela que lhe seria imposta caso aceitasse a proposta. Isso possibilita, segundo Vasconcellos (2015, p. 172), a superveniência de "condenações que seriam inviáveis em julgamento em conformidade com o devido processo penal", na medida em que a coerção exercida sobre acusado é tamanha que lhe faz consentir com a concretização antecipada do poder punitivo estatal mesmo - não raras vezes - não sendo ele o efetivo autor das alegadas condutas delituosas. ${ }^{19}$

\footnotetext{
${ }_{19} \mathrm{Em} \mathrm{1985}$, seis indivíduos foram acusados do estupro e assassinato de Helen Wilson, residente de Beatrice, pacata cidade em Nebraska (EUA), no que ficou conhecido como "The Beatrice Six". Dos seis réus, cinco alegaram ser culpados (plead guilty), confessando a prática do crime, uma vez que, se condenados pelo Júri, poderiam ser sentenciados à pena de morte. Em 2008, no entanto, o único réu que não havia se declarado culpado, Joseph White, conseguiu direito à realização de novo teste de DNA em evidências preservadas da cena do crime, ao que ficou comprovado que nenhum dos seis havia participado do delito. Segundo os testes realizados, o assassino, na verdade, era Bruce Allen Smith, residente temporário daquela cidade, que havia morrido em 1992. Dentre os cinco réus que haviam aceito o acordo de barganha, mesmo sendo efetivamente inocentes, três testemunharam contra Joseph White em troca de benefícios na condenação. Ao todo, os seis acusados cumpriram 70 anos de prisão.
} 
Tal cenário, de inexorável coercibilidade, enseja, por evidente, um absoluto aviltamento à presunção de inocência em sua perspectiva como dever de tratamento, haja vista a existência de um interesse da acusação (frequentemente aquiescido pelo Judiciário) em que o imputado consinta com a antecipação da sanção penal, satisfazendo-se, integralmente, sem a existência de um devido processo e, portanto, sem a observância das garantias conformadoras de um sistema processual efetivamente democrático: a pretensão acusatória.

\subsection{0 direito à (ampla) defesa e à garantia do contraditório}

Conforme assinalado no início deste artigo, o direito à (ampla) defesa e à garantia do contraditório representam princípios constitutivos do devido processo legal, cuja elevada importância justificou a expressa inclusão deles no rol de direitos e garantias individuais previstos na Constituição Federal.

Em primeiro lugar, cumpre esclarecer que, a despeito de possuírem significados semelhantes, os dois princípios se identificam com esferas protetivas diferentes. Em que pese essa distinção - de natureza precipuamente teórica -, é possível observar, entre eles, uma íntima relação de reciprocidade. Como afirma Ada Pellegrini Grinover et al. (1992),

defesa e contraditório estão indissoluvelmente ligados, porquanto é do contraditório (visto em seu primeiro momento, da informação) que brota o exercício da defesa; mas é esta - como poder correlato ao de ação que garante o contraditório. A defesa, assim, garante o contraditório, mas também por este se manifesta e é garantida (p. 63).

Com efeito, pode-se compreender o contraditório, de um lado, como direito à informação, relacionando-se à imprescindibilidade de que seja oportunizado às partes o conhecimento a respeito de todos os elementos fáticos e jurídicos atinentes ao caso penal em análise. De outro lado, esse princípio manifesta-se como direito à reação, na medida em que não basta simplesmente estabelecer as condições para que as partes conheçam o processo: é necessário que elas possam, de maneira efetiva, em posição de igualdade, influenciar a formação do convencimento do julgador. ${ }^{20}$

O direito à ampla defesa, por sua vez, exsurge a partir do imperativo de que o réu possa conhecer o processo e nele efetivamente atuar (ou reagir). Diferentemente, contudo, do contraditório - que incide tanto em favor da acusação quanto do acusado -, a ampla defesa se destina fundamentalmente a este último, materializando-se em duas dimensões: defesa técnica e defesa pessoal.

Num primeiro momento, como defesa técnica, este princípio pressupõe "a existência de uma pessoa com conhecimentos teóricos do Direito, um profissional, que será tratado como advogado de defesa, defensor ou simplesmente advogado" (LOPES JR., 2017, p. 98). Nessa toada, afigura-se mister garantir ao acusado a assistência jurídica de um profissional que detenha vasto conhecimento técnico, suficiente para enfrentar, de maneira paritária, as hipóteses acusatórias ventiladas pelo querelante ou pelo Ministério Público.

O fundamento deste princípio, segundo preleciona Lopes Jr., decorre da "exigência de equilíbrio funcional entre defesa e acusação e também de uma acertada presunção de hipossuficiência do sujeito passivo, de que ele não tem conhecimentos necessários e suficientes para resistir à pretensão estatal, em igualdade de condições com o acusador" (LOPES JR., 2017, p. 98). Nesse diapasão, presume-se que o réu, isoladamente, não possui condições de combater, de maneira igualitária, as acusações que lhe recaiam, exigindo-se, portanto, a assistência de um profissional especializado que satisfaça essa lacuna.

Em razão da natureza pública, que perpassa a dimensão principiológica em comento, sustenta a doutrina - sendo pacificamente acompanhada pela jurisprudência ${ }^{21}$ - que a defesa técnica consiste em garantia indisponível. Com efeito, além de se apresentar como instrumento protetivo individual do sujeito passivo, é possível observar um interesse social (ou metaindividual) de que o caso penal seja corretamente apurado, evitando que pessoas inocentes sejam injustamente submetidas a uma sanção penal. Por tal razão, não se faculta

\footnotetext{
${ }^{20}$ Nesse sentido, afirma Lopes Jr., com arrimo nos ensinamentos de Elio Fazzalari, que o contraditório "deve ser visto em duas dimensões: no primeiro momento, é o direito à informação (conhecimento); no segundo, é a efetiva e igualitária participação das partes. É a igualdade de armas, de oportunidades" (LOPES JR., 2017, p. 98).

${ }^{21}$ Nessa direção, enuncia a Súmula 523 do Supremo Tribunal Federal: "No processo penal, a falta da defesa constitui nulidade absoluta, mas a sua deficiência só o anulará se houver prova de prejuízo para o réu".
} 
ao réu, a pretexto de "simplificar" ou "baratear" o processo, que renuncie à defesa técnica, de modo que, não podendo arcar com os custos advindos de um patrocínio jurídico, deve o Estado fornecer-lhe assistência gratuita e efetiva.

Noutro viés, extrai-se da ampla defesa um postulado de defesa pessoal (ou autodefesa) representado pela faculdade, que se apresenta ao acusado de atuar "pessoalmente, defendendo a si mesmo como indivíduo singular, fazendo valer seu critério individual e seu interesse privado" (LOPES JR., 2017, p. 101). Distintamente da dimensão antes analisada, a autodefesa afigura-se como garantia renunciável, remetendo-se ao "âmbito de conveniência do réu, que pode optar por permanecer inerte, invocando, inclusive, o silêncio" (TÁVORA; ALENCAR, 2017, p. 77).

Questão assaz problemática diz respeito à (indevida) importação dos instrumentos de justiça negocial ante o ordenamento jurídico pátrio. De fato, os acordos processuais realizados entre acusação e defesa pressupõem, a partir de uma subvertida lógica eficientista, a simplificação do procedimento que normalmente deveria ser observado caso nenhum acordo sobreviesse.

Nessa senda, Bernd Schünemann, importante jurista alemão, ao discorrer acerca dos motivos que justificam a crescente tendência de importação dos institutos norte-americanos à realidade penal latina, afirma que é precisamente a simplificação (e consequente aceleração) procedimental a razão que subjaz a hodierna "marcha triunfal do modelo norte-americano do processo penal". Segundo esclarece o autor:

Acredito (o que à primeira vista parece paradoxal) estarem estes motivos ancorados exatamente nas suas debilidades, nos seus déficits em relação aos mandames do estado de direito, pois que neste modelo, por trás da reluzente fachada de um modelo ideal - o adversarial -, para mais de $90 \%$ dos casos vige algo bem diverso: uma prática de sentenciamento acelerado, levada a cabo pelos órgãos de investigação sem qualquer controle judicial sério. Não é sua conformidade com os valores do estado de direito, mas são pelo contrário suas debilidades, que fazem hoje em dia o sistema norte-americano parecer tão atraente para os órgãos de persecução penal europeus e para a legislação por estes influenciada (SCHÜNEMANN, 2013, p. 242).

Essa simplificação acarreta, dentre outras consequências, a renúncia (não raras vezes involuntária, em razão dos intensos mecanismos coercitivos que circundam os expedientes negociais, como já sublinhado) do direito fundamental de defesa do acusado. Com efeito, para que os pretensos benefícios decorrentes do acordo possam incidir, o réu precisa declaradamente renunciar ao seu direito de defesa, abdicando, por conseguinte, da possibilidade de produzir provas e, em última análise, assentindo com o completo esvaziamento do mais importante instrumento de defesa do indivíduo ante o poder estatal, garantidor de um processo efetivamente justo e democrático e conformador de uma episteme processual fundamentalmente garantista e acusatória - o devido processo legal.

\section{NOTAS CONCLUSIVAS}

A partir das reflexões desenvolvidas neste trabalho, resta agora possível concluir que:

1. A Constituição da República Federativa do Brasil perfilhou uma série de garantias limitadoras do exercício do poder punitivo do Estado. Essas garantias encontram-se consubstanciadas na cláusula constitucional do devido processo legal, e exigem, à efetiva e legítima aplicação de uma pena, que o conjunto normativo limitador do poder punitivo seja rigorosamente observado.

2. A partir da cláusula do devido processo legal, é possível extrair um conjunto de normas responsável por constituir o sistema epistemológico garantista. Essas normas materializam-se destacadamente no princípio da jurisdicionalidade; no princípio acusatório (separação entre as atividades jurisdicionais e acusatórias); na obrigatoriedade da ação penal; na presunção de inocência; no direito à ampla defesa; e no direito ao contraditório.

3. Os mecanismos de justiça negocial são instrumentos jurídicos que visam essencialmente à simplificação do procedimento penal, com vistas a torná-lo supostamente mais efetivo. Sucede que, a pretexto de simplificar o caminho necessário à aplicação de uma pena, os referidos institutos terminam por relativizar (ou, em casos mais extremos, suprimir) garantias fundamentais, as quais, por força de sua natureza constitucional, deveriam ser compreendidas como absolutamente insuscetíveis a medidas que importassem na diminuição de sua carga axiológico-normativa. 
4. Nesse diapasão, percebeu-se que os instrumentos negociais ensejam, primeiramente, o esvaziamento teleológico da garantia da jurisdicionalidade (mormente em seu sentido estrito), na medida em que permitem a aplicação de uma pena a despeito da inexistência de um processo penal devidamente instruído.

5. Além disso, verificou-se que os instrumentos consensuais promovem relativização à obrigatoriedade da ação penal, uma vez que os acordos processuais reclamam a abertura de um espaço de discricionariedade (ainda que limitada em Lei) por meio da qual se apresenta à acusação a possibilidade de não oferecimento da denúncia ainda que os requisitos determinantes da instauração do processo estejam presentes. Isso torna-se sobremaneira problemático ao oportunizar ao órgão acusador o exercício de um juízo incondicional ou ilimitado (e por isso mesmo arbitrário) relativamente à necessidade da propositura do acordo, o que contraria, ademais da obrigatoriedade da ação penal, os princípios da legalidade e da igualdade.

6. Do mesmo modo, foi possível constatar que os mecanismos de justiça negocial afiguram-se potencialmente prejudiciais à tutela do princípio da presunção de inocência. Isso ocorre, em primeiro lugar, em razão do inegável contexto de coercibilidade social e jurídica que circunda a propositura do acordo, responsável por conduzir pessoas inocentes a declararem-se culpadas em razão do receio de serem mais severamente punidas.

7. Além disso, verificou-se frontal prejuízo à tutela da inocência em sua perspectiva probatória, uma vez que, havendo supressão da fase instrutória-processual - assim como dos direitos a ela correlatos (como a ampla defesa e o contraditório) -, não se queda possível confrontar a conformidade dos elementos informativos em relação às normas procedimentais a eles previstas.

8. Finalmente, é também possível depreender dos mecanismos negociais um gravoso e inadmissível fortalecimento de uma estrutura processual inquisitória.

9. Nesse sentido, considerando que os mecanismos negociais se fundamentam nos dois elementos mais determinantes da estrutura processual inquisitória - quais sejam, o segredo (em razão da prevalência do inquérito e dos atos de investigação) e a confissão (em virtude destacada importância conferida às declarações autoincriminatórias) -, conclui-se que os instrumentos de justiça consensual têm o condão de proceder ao reforço de um processo penal cuja práxis já se revela lastimavelmente contaminada por práticas autoritárias.

10. Por todo o exposto, é possível concluir que os mecanismos de justiça negocial representam potenciais obstáculos à efetiva tutela dos direitos e garantias fundamentais. Nesse contexto, tem-se que, caso efetivamente recepcionados no ordenamento jurídico pátrio, as propostas hodiernas de ampliação dos espaços de consenso poderão agravar um sistema jurídico já muito calejado por uma mentalidade punitivista, que se manifesta a partir de práticas inquisitórias deletérias à Constituição da República e ao Estado Democrático de Direito.

\section{REFERÊNCIAS}

ALENCAR, Rosmar Antonni Rodrigues Cavalcanti. Limites jurídicos da delação premiada e a necessidade de controle recursal contra a sentença homologatória. Revista Parahyba Judiciária, v. 11, 2018, p. 413-439. Disponível em: https://jfpe.gov. br/images/stories/docs_pdf/biblioteca/artigos_periodicos/RosmarAntonniRodriguesCdeAlencar/Limites_parahyba_judiciaria_n11_2018.pdf. Acesso em: 16 mar. 2019.

ALSCHULER, Albert W. "Plea Bargaining and Its History". Columbia Law Review, v. 79, Columbia, 1979.

AMARAL, Augusto Jobim do. A pré-ocupação de inocência no processo penal. Rev. Fac. Direito UFMG, Belo Horizonte, n. 62, p. 85-115, jan./jun. 2013.

ANITUA, Gabriel Ignacio. A importação de mecanismos consensuais do processo estadunidense nas reformas processuais latino-americanas. In: GLOECKNER, Ricardo Jacobsen (org.). Sistemas Processuais Penais. Florianópolis: Empório do Direito, 2017.

BARROS, Flaviane Magalhães. (Re)forma do Processo Penal: comentários críticos dos artigos modificados pelas Leis n. 11.690/08, n. 11.719/08 e n. 11.900/09. 2. ed. Belo Horizonte: Del Rey, 2009.

BOSCHI, José Antonio Paganella. $O$ devido processo legal: escudo de proteção do acusado e a práxis pretoriana. Revista Brasileira de Ciências Criminais, v. 58, p. 232 a 279, jan./fev. 2006. 
CARVALHO, Amilton Bueno de. Lei, para que $(m)$ ? Escritos de Direito e Processo Penal em homenagem ao Professor Paulo Cláudio Tovo. Coord. Alexandre Wünderlich. Rio de Janeiro: Lumen Juris, 2001.

CARVALHO, Salo de. Antimanual de criminologia. 6. ed. São Paulo: Saraiva, 2015.

CIRINO DOS SANTOS, Juarez. Direito Penal - Parte Geral. 5. ed. Florianópolis: Conceito Editoral, 2002.

CORDERO, Franco. Guida allá procedura penale. Torino: Utet, 1986.

CUNHA MARTINS, Rui. A hora dos cadáveres adiados: corrupção, expectativa e processo penal. São Paulo: Atlas, 2013. p. 3.

CUNHA MARTINS, Rui. O ponto cego do Direito: The Brazilian Lessons. 2. ed. Rio de Janeiro: Lumen Juris. 2011.

DIEGO DÍEZ, Luis Alfredo de. Justicia criminal consentuada. Algunos modelos del derecho comparado em los EE.. UU, Italia y Portugal. Valencia: Tirant lo Blanch, 1999.

FERRAJOLI, Luigi. Direito e razão: teoria do garantismo penal. São Paulo: Revista dos Tribunais, 2002.

GLOECKNER, Ricardo Jacobsen. Autoritarismo e processo penal: uma genealogia das ideias autoritárias no processo penal brasileiro. Florianópolis: Empório do Direito, 2018.

GRINOVER, Ada Pellegrini et al. As nulidades no Processo Penal. 2. ed. São Paulo: Malheiros, 1992.

HEUMANN, Milton. Plea bargaining. The experiences of prosecutors, judges and defense attorneys. Chicago: The University of Chicago Press, 1981.

LAMAS, Lívia Paula de Almeida. Aplicação da pena nos Estados Democráticos de Direito à luz do garantismo: aspectos polêmicos do Código Penal brasileiro. 2010. 101 f. Dissertação (Mestrado) - PUC-RIO. Rio de Janeiro, 2010.

LOPES JR., Aury. Direito processual penal. 14. ed. São Paulo: Saraiva, 2017.

LOPES JR., Aury. Fundamentos do processo penal: introdução crítica. 4. ed. São Paulo: Saraiva, 2018.

LOPES JR., Aury; GLOECKNER, Ricardo Jacobsen. Investigação preliminar no Processo Penal. 6. ed. São Paulo: Saraiva, 2014.

LOPES, Marcos Antônio. De Deus ao Rei: O direito sagrado do mando (implicações teológico-religiosas na teoria política moderna). Sínteses, n. 118, 2010, p. 216 et seq. Disponível em: http://www.faje.edu.br/periodicos/index.php/Sintese/article/ view/848/1277. Acesso em: 23 mar. 2019.

MORAES, Maurício Zanoide de. Presunção de inocência no processo penal brasileiro: análise de sua estrutura normativa para a elaboração legislativa e para a decisão judicial. Rio de Janeiro: Lumen Juris, 2010.

MORAIS DA ROSA, Alexandre; LOPES JR., Aury. Com delação premiada e pena negociada, Direito Penal também é lavado a Jato. Delação premiada no limite: a controvérsia justiça negocial made in Brazil. Florianópolis: EMais, 2018.

MUÑOZ CONDE, Francisco. De las prohibiciones probatorias al Derecho procesal penal del enemigo. Revista Penal, n. 23, p. 73-114, 2008, p. 73.

PAVÓN, Pilar Gomes. Cuestiones Actuales del Derecho Penal Económico: el Principio de Legalidad y las Remisiones Normativas. Revista Brasileira de Ciências Criminais, São Paulo: Revista dos Tribunais, v. 48, p. 108 a 163, maio/jun. 2004.

PRADO, Geraldo. Prova penal e sistema de controle epistêmicos: a quebra da cadeia de custódia das provas obtidas por métodos ocultos. 1. ed. São Paulo: Marcial Pons, 2014.

SCHÜNEMANN, Bernd. Do templo ao mercado? Sistemas Processuais Penais. Org. Ricardo Jacobsen Gloeckner. Florianópolis: Empório do Direito, 2017.

SCHÜNEMANN, Bernd. Um olhar crítico ao modelo processual penal norte-americano. Trad. Danielle Soares Delgado Campos. In: SCHÜNEMANN, Bernd. Estudos de direito penal, direito processual penal e filosofia do direito. São Paulo: Marcial Pons, 2013.

TÁVORA, Nestor; ALENCAR, Rosmar. Curso de Direito Processual Penal. 12. ed. Salvador: JusPodivm, 2017.

VASCONCELLOS, Vinicius Gomes. Barganha e justiça criminal negocial: análise das tendências de expansão dos espaços de consenso no processo penal brasileiro. São Paulo: IBCCRIM, 2015. 